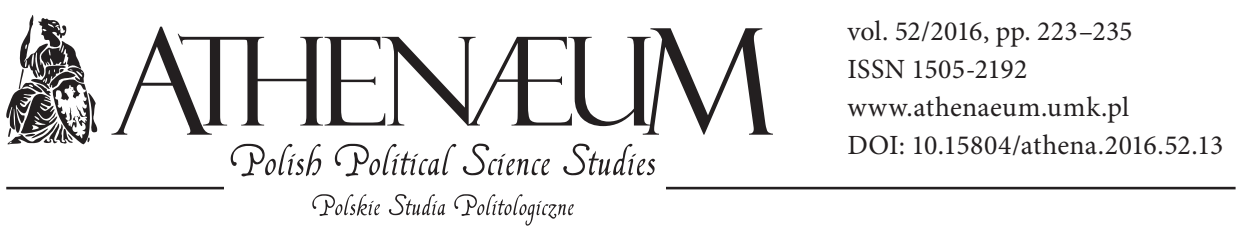

\title{
THE STRUCTURE \\ OF TRANSITIONAL REMEMBRANCE POLICY. A REPORT ON INTERNAL CORRELATIONS*
}

\author{
STRUKTURA TRANZYCYJNEJ POLITYKI HISTORYCZNEJ. \\ RAPORT Z BADAŃ KORELACJI WEWNĘTRZNYCH
}

Joanna Marszałek-Kawa**, Patryk Wawrzyński***

\begin{abstract}
The research report presents results of the comparative study on relationships between remembrance narratives and transitional identity policy. It is based on the qualitative-toquantitative narrative analysis of six cases: Chile, Estonia, Georgia, Poland, South Africa, and Spain. It discusses internal correlations within the structure of transitional remembrance policy with reference to three levels of analysis: the general level, the areas of impact (objectives of the policy) level, and the fields of impact (aims of the policy) level. As a result, it offers two models - the General Model of Correlations, and the Model of Internal Correlations. These two drawings show main features of remembrance story-telling during democratisations, and they develop present
\end{abstract}

Raport prezentuje wyniki badań porównawczych nad związkami między narracjami pamięci a tranzycyjną polityką tożsamości. Badania zrealizowane zostały poprzez zastosowanie jakościowo-ilościowej analizy narratywnej sześciu przypadków: Chile, Estonii, Gruzji, Hiszpanii, Polski i Południowej Afryki. Artykuł omawia wewnętrzne korelacje w ramach struktury tranzycyjnej polityki historycznej w odniesieniu do trzech poziomów analizy: ogólnego, przestrzeni oddziaływania (celów polityki) i pól oddziaływania (zadań polityki). W efekcie przedstawia dwa modele - ogólny model korelacji i model korelacji wewnętrznych. Nakreślają one najważniejsze cechy opowiadania o przeszłości w toku demokratyzacji i rozwijają obecne rozumienie

* The paper is a result of the research project Politics of Memory as the Constitutional Factor of New Identities during the Transition from Authoritarian Regimes financed from the funds of the National Science Center in Kraków, Poland, on the basis of the decision no. DEC-2012/05/E/ HS5/02722. Acknowledgments: the Authors express their gratitude to their colleagues - Dr Anna Ratke-Majewska and Dr Joanna Piechowiak-Lamparska, fellow investigators in the project.

** Nicolaus Copernicus University in Toruń, Faculty of Political Sciences and International.

$* * *$ WSB University in Bydgoszcz, Faculty of Finances and Management, Nicolaus Copernicus University in Toruń, Faculty of Political Sciences and International Studies. 
understandings on the way in which historical arguments may influence transitional identity reconstruction.

Keywords: remembrance narratives, story-telling, democratisation, transformations, comparative analysis sposobu, w jaki argumenty historyczne mogą oddziaływać na tranzycyjną rekonstrukcję tożsamości narodowej.

Słowa kluczowe: narracje pamięci, opowiadanie, demokratyzacja, transformacje, analiza porównawcza

\section{POLITICS OF DEMOCRATISATION AND REMEMBRANCE STORY-TELLING}

The changes of the last four decades has established democratisation as the key concept within contemporary political science. Following Barbara Geddes (1999), we may ask ourselves what do we know about this process, and are we closer to understand how it develops and changes social and political structures. Previous studies have showed us how democratisation influences economic growth (Papaioannou \& Siourounis, 2008) and what are its origins, general features and basic rules (Blind, 2013; Bogaards, 2016; Capoccia \& Ziblatt, 2010; Geddes, 2009; Godlewski, 2014; Kadivar \& Caren, 2016). However, we may still identify spaces where the democratisation seems to be unexplored, and where political science is not able to deliver explanations based on research evidence. One of these topics is a dynamic of relationships between the democratisation and remembrance story-telling.

Despite the advanced development of political science and memory studies over recent decades, the consolidation of these disciplines has not been realised yet. We know that remembrance narratives are an effective political asset to legitimise government's strategies, decisions or actions, to shape contents of social identities and shared values, to mobilise citizens and involve them in ongoing political processes, as well as to manipulate citizens' commitment to the public life (Khalili, 2007, p. 222; Westen, 2008, p. 41-49; Wawrzyński, 2015, p. 160-166; Wawrzyński et al., 2015, p. 126-127; Kącka, 2015, p. 63-66). The interest in a role of politicised remembrance during political transitions has led us to the question of how governments use interpretations of the past to support their policy during democratisations. But we have not stopped there and we have followed it with another question: what we can learn about the nature of democratisation from the structure of transitional remembrance story-telling? 
In this report we would like to present some results of our comparative study on relations between transitional identity politics and the government's remembrance policy (Marszałek-Kawa \& Wawrzyński, 2016). We have investigated how transitional political leadership uses interpretations of the national history to support the promoted vision of a democratic society. Therefore, we have placed the politicised remembrance in the complex landscape of transitional narratives and we have referred it to the future-oriented nature of democratisation. The application of qualitative-to-quantitative narrative analysis enabled us to code collected data, and - then - to observe relationships within a structure of transitional remembrance story-telling. As a result, we were able to measure a degree of significance for different items ${ }^{1}$ and a strength of correlations between them. Moreover, we were able to draw evidence-based models of the government's remembrance policy during democratisation.

In our study we compared six cases of post-authoritarian transformations in Chile, Estonia, Georgia, Poland, South Africa, and Spain. The selected sample represented different types of democratisation and each country is characterised by different features (Marszałek-Kawa et al., 2016a, p. 9-10; Marszałek-Kawa et al., 2016b, p. 19-21). Our investigations considered eight areas of transitional story-telling as legitimisation of: (1) new elites, (2) former elites presence in postauthoritarian public life, (3) adopted model of transitional justice or a lack of it, (4) social and economic costs of transformations, (5) introducing new social and political standards, (6) symbolic roles of democratisation, (7) need for national unity, and (8) new state's role in international politics. These areas were divided into thirty-seven fields of impact that represented individual aspects where the multifactor analysis and the extended literature review showed possible links between transitional identity politics and remembrance story-telling. This division enabled us to observe the structure on three different levels: the general comparative level, the areas of impact level, and the fields of impact level. As a result, we were able to identify significant relations not only between same-class items, but also to cross all three levels of analysis and to discuss advanced features of the transitional remembrance policy.

${ }^{1}$ In the study we used a five-level Likert-type scale, where 1 point represented very low degree of impact on identity politics during democratisation, 2 points - low degree, 3 points - moderate degree, 4 points - high degree, and 5 points - very high degree (see: Marszałek-Kawa \& Wawrzyński, 2016). 


\section{THE GENERAL MODEL OF CORRELATIONS}

The fundamental aspect of our study was to identify correlations between the general shape of transitional remembrance story-telling and individual aspects of this process. On the second level of analysis, we have noticed that the most significant influence on a degree in which governments used remembrance narratives had presentation of symbolic - trans - and intergenerational - roles of democratisation $(r=0.96)$ and explanation of social and economic costs of transformation $(r=0.91)$. Less influential were legitimisation of the transitional justice $(r=0.71)$ and explanation of new social and political standards $(r=0.67)$. Correlations for other four research categories - as it is presented on Image 1. - were weak and rather irrelevant to the general model.

On the third level of analysis our comparative study has delivered some informative observations that may help us to understand which aspects of the remembrance story-telling are essential during democratisations. The strongest correlations we have observed for two fields of impact - use of the national history to explain adopted procedures of transitional justice as a punishment of human rights violators or authoritarian criminals (item $3-2 ; \mathrm{r}=0.81$ ), and adaptation of popularised narratives on the past to symbolic needs of the democratisation $(6-3 ; \mathrm{r}=0.84)$. Moreover, the first item was strongly correlated with the explanation of social and economic costs of transformation $(r=0.96)$, while the second one with the presentation of symbolic roles of the changes ( $\mathrm{r}$ $=0.91$ ), therefore, their relations with the general shape are clearly seen on two different levels.

The discovery of these multi-level relationships has encouraged us to consider an indirect influence on the general shape. We have noticed that there are two relevant areas of impact and two relevant fields of impact. Thus, we asked ourselves, which items were correlated with their average scores. For social and economic costs that were: transitional justice as a legitimisation of the rule of law $(3-1 ; \mathrm{r}=0.87)$, discussed above transitional justice as a punishment for human right violators $(3-2 ; \mathrm{r}=0.96)$, and new organisation of time as a medium to transfer ideas from elites to the society $(6-5 ; \mathrm{r}=0.84)$. For symbolic roles of democratisation that were: remembrance narratives as an inspiration for a new definition of patriotism ( $5-4 ; \mathrm{r}=0.84)$, discussed above adaptation of stories to needs of the democratisation $(6-3 ; r=0.91)$, and narratives on national heroes as a source of knowledge on democratic and civic models of political behaviour $(6-4 ; r=0.90)$. When we moved to the field of impact level, we noticed that 
transitional justice as a punishment was observably correlated with three items: presentation of dealing with the past as a legitimisation of the rule of law ( $3-1 ; \mathrm{r}$ $=0.85$ ), historical justifications of new economic attitudes and behaviours (4-2; $\mathrm{r}=0.88)$, and new organisation of time as means to transfer ideas from elites to the society $(6-5 ; \mathrm{r}=0.88)$, while the pro-democratic selection of narratives was correlated with: explanation of former elites presence in public life as a historical legitimisation of democracy $(2-2 ; \mathrm{r}=0.85)$, remembrance narratives as an inspiration for a new definition of patriotism $(5-4 ; \mathrm{r}=0.88)$, national heroes as role models of democratic and civic behaviour $(6-4 ; \mathrm{r}=0.87)$, and the past as a justification of the need for national unity $(7-1 ; \mathrm{r}=0.94)$.

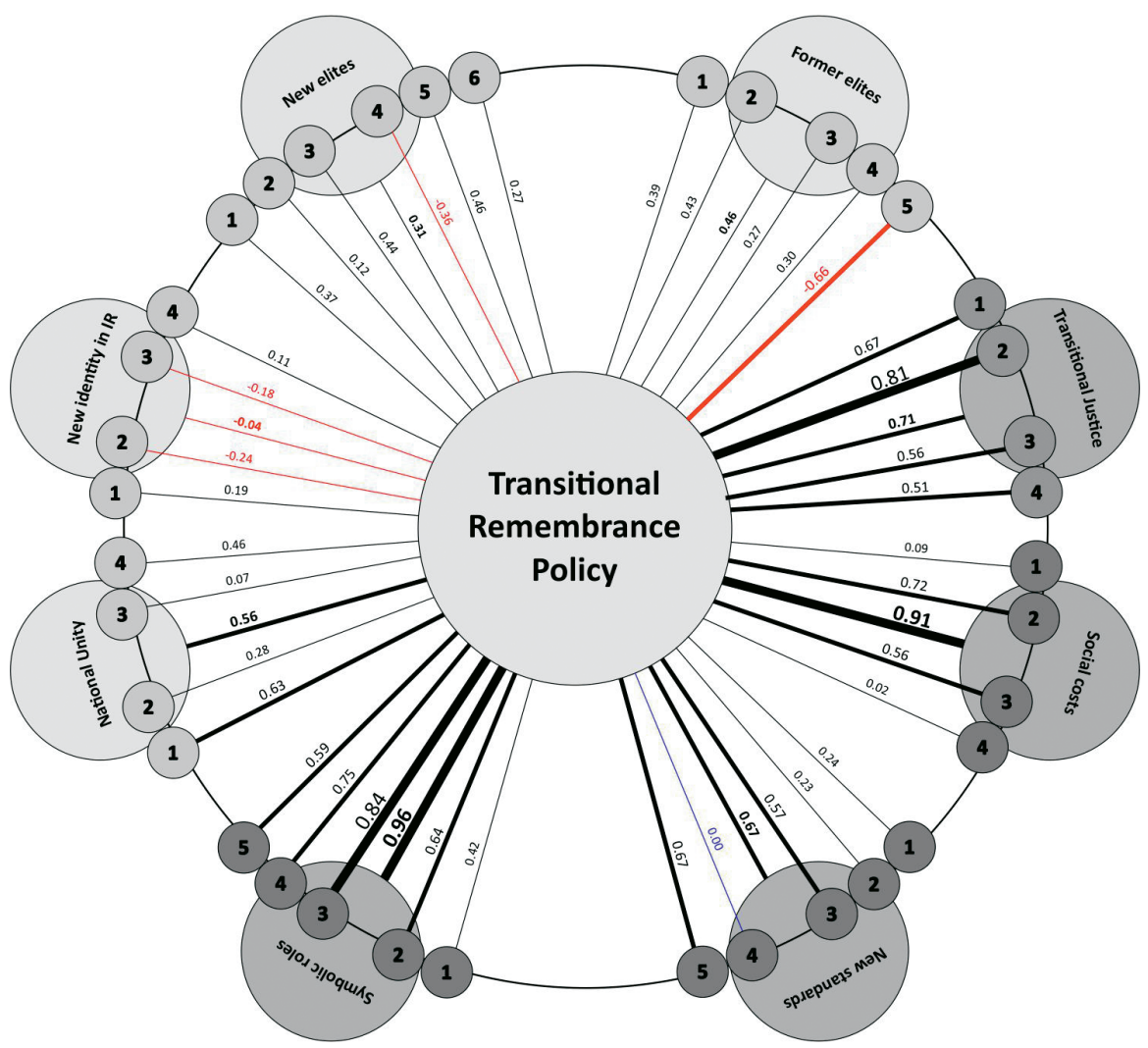

Image 1. The General Model of Correlations between the shape of transitional remembrance policy and its objectives and aims. In black—positive correlations, in red-negative correlations

Source: Marszałek-Kawa et al., 2016b, p. 103. 
It is obvious that two fields of impact that are directly correlated with the general shaper - transitional justice as a punishment (3-2) and pro-democratic selection of narratives (6-3) - are essential for the structure of transitional remembrance policy. But what about other aspects of story-telling during democratisation? Four items - transitional justice as a legitimisation of the rule of law (3-1), remembrance narratives as an inspiration for a new definition of patriotism (5-4), commemoration of national heroes as a source of democratic and civic role models (6-4), and new organisation of time as means to transfer ideas from elites to the society $(6-5)$ - were correlated both with relevant areas and relevant field, so they should also be considered as essential for the structure. Among remaining four items we agreed to highlight two - historical explanations of new economic attitudes and behaviours (4-2), and the past as a legitimisation of the need for national unity $(7-1)$ - that were semi-relevant to the general shape of transitional remembrance story-telling $(4-2: \mathrm{r}=0.72,7-1: \mathrm{r}$ $=0.63)$. As a result, our considerations delivered a draft theoretical framework of eight significant relationships within the structure of transitional remembrance policy (described with reference to a process of identity reconstruction during democratisation). This framework not only informs us about the way how governments narrate the past and transform the remembrance into a valuable political asset, but it also shows which narrative aspects increase the general significance of historical argumentation during post-authoritarian transformations. Therefore, these results may lead us to interesting conclusions on the nature of the democratisation in general, as they show which topics are more significant for intensity of transitional government's remembrance story-telling (MarszałekKawa et al., 2016b, p. 102-108).

\section{THE MODEL OF INTERNAL CORRELATIONS}

It is obvious that the General Model presents only a small part of the complex picture. It only slightly discusses relationships between items, which - as we have shown in the case of indirect correlations - can be used to answer a question: what shapes transitional remembrance policy? In fact, we may consider at least three different groups of these relationship that can be classified with reference to levels of analysis. And inclusion of them enables us to identify another features of remembrance story-telling during democratisations. 
Firstly, we measured how strong correlations are between areas of impact (objectives of the policy). Besides two significant relations between the general shape and categories that we have discussed in the previous section, we have observed three interesting links within investigated area. The strongest one characterised relationship between justification of the selected model of transitional justice and explanation of social and economic costs of transformations ( $\mathrm{r}=$ $0.85)$. Social costs were also linked with symbolic roles of the change $(r=0.83)$, a fact which one cannot be surprised by in the face of previously discussed general results. Moreover, legitimisation of the presence of former regime's representatives in the nation's public life was significantly correlated with the use of the past to justify the historical need for national unity $(\mathrm{r}=0.81)$. Other relations between categories were weaker and in few cases there was almost no correlations between individual areas of impact.

Secondly, we studied correlations within areas of impact. In general, we identified thirteen cases of strong relationships that should be included in our considerations of the transitional remembrance's structure. The legitimisation of new elites was influenced by the use of the past to justify their dominant position (item $1-1 ; r=0.86$ ), use of national symbols and heroes as a source of legitimisation $(1-3 ; \mathrm{r}=0.80)$, and justification of their position as a result of historical necessity of internal conflicts prevention $(1-5 ; \mathrm{r}=0.88)$. The explanation of former elites' presence in democratic life was correlated with explanation of their involvement as a legitimisation of democracy and pluralism $(2-2 ; \mathrm{r}=$ 0.89 ) and as a definition of the democratic competition and the pluralist society $(2-3 ; r=0.96)$. The justification of transitional justice procedures was connected with its presentation as a legitimisation of the rule of law $(3-1 ; r=0.96)$ and as a source of forgiveness $(3-2 ; r=0.96)$. In case of social and economic costs and popularisation of new social and political standards, no strong internal correlations were observed in the selected sample. The explanation of symbolic roles of the change was highly influenced by pro-democratic selection of narratives $(6-3 ; r=0.91)$ and presentation of national heroes as role-models of democratic and civic behaviour $(6-4 ; \mathrm{r}=0.90)$. The justification of the need for national unity was observably connected with the use of the past as a reason for national unity $(7-1 ; \mathrm{r}=0.89)$ and historical motivation for reconciliation and forgiveness $(7-2 ; r=0.83)$. The last category, the new state's identity in international politics, was correlated with the use of the past as a reason for new international aspirations of a country $(8-1 ; r=0.90)$ and presentation of new role within the 
international community as an accomplishment of transitional objectives and a historical challenge $(8-2 ; r=0.93)$. It shows that only fourteen of thirty-seven aims of remembrance policy have an impact on the way in which governments realise transitional objectives of historical story-telling.

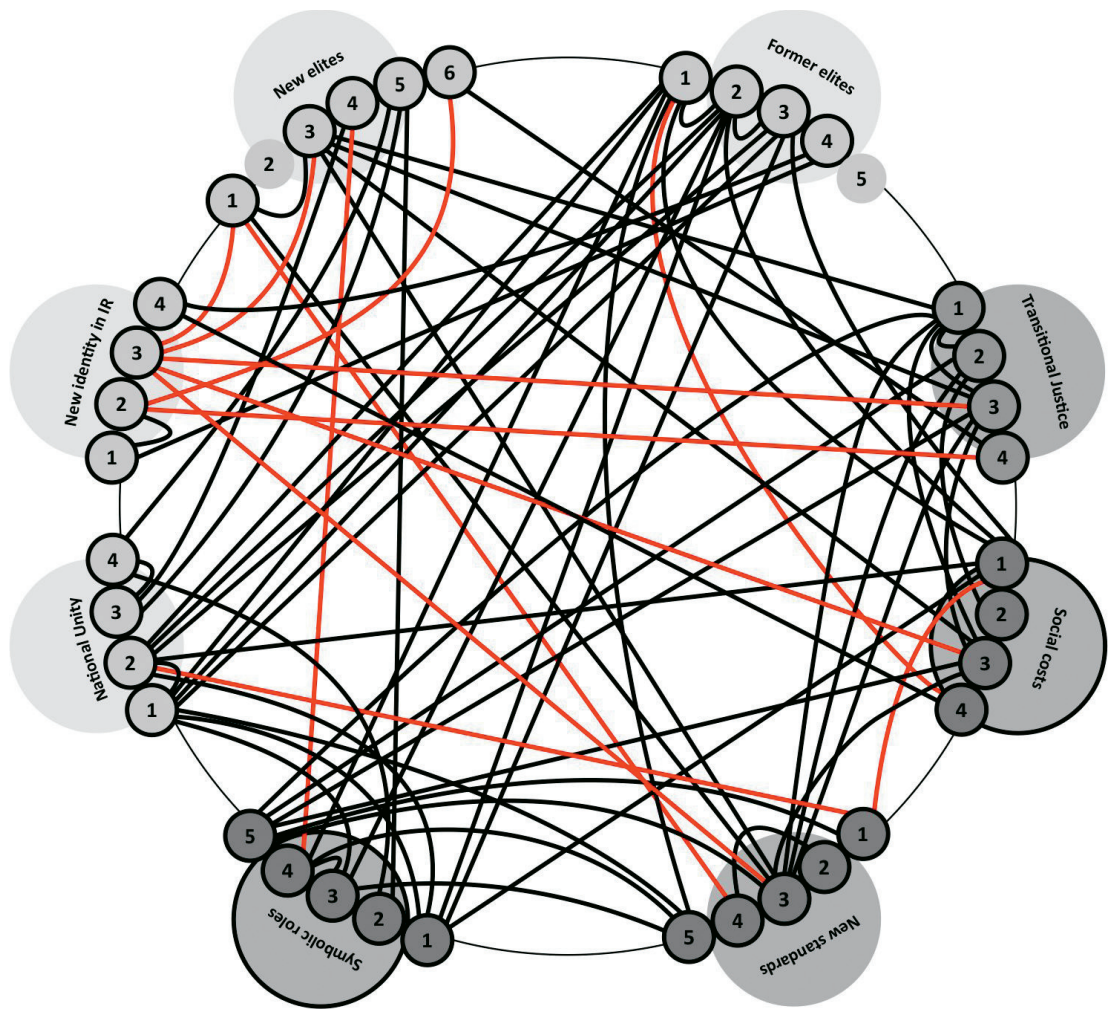

Image 2. The Model of Internal Correlations between the transitional remembrance policy's fields of impact, including correlations stronger than $r=0.80$. In black positive correlations, in red-negative correlations

Source: Marszałek-Kawa et al., 2016b, p. 72.

Thirdly, we investigated correlations between individual fields of impact (aims of the policy). Within categories we observed ten of them - item 1-1 with item $1-3(\mathrm{r}=0.82), 2-1$ with $2-2(\mathrm{r}=0.89), 2-2$ with $2-3(\mathrm{r}=0.94), 3-1$ with $3-2$ $(\mathrm{r}=0.85)$ and with $3-3(\mathrm{r}=0.98 !), 5-2$ with $5-4(\mathrm{r}=0.88), 6-3$ with $6-4(\mathrm{r}$ $=0.87), 7-1$ with $7-2(\mathrm{r}=0.88), 7-3$ with $7-4(\mathrm{r}=0.87)$, and $8-1$ with $8-2$ 
$(\mathrm{r}=0.80)^{2}$. Besides them, we identified other thirty-nine positive correlations between categories and next - twelve negative ones. The composition of them enabled us to draw the Model of Internal Correlations - presented on Image 2. - which offers a complex map of all observed strong correlations between fields of impact. For items assigned to new political elites we noticed eleven positive and five negative relations, for presence of former elites - eighteen positive and one negative, for transitional justice - fourteen positive and two negative, for social and economic costs - twelve positive and three negative, for new social and political standards - thirteen positive and four negative, for symbolic roles of democratisation - nineteen positive and one negative, for national unity seventeen positive and one negative, and finally, for new role in international politics - four positive and seven negative correlations (Marszałek-Kawa et al., 2016b, p. 75-80).

The Model of Internal Correlations shows us which spheres of transitional remembrance policy have the most significant impact on its other objectives or aims. On average, the highest correlations rate per a field characterises the need for national unity (5.00) that has the strongest links with the presence of former regime's representatives and the explanation of democratisation's symbolic roles. Slightly less correlations per one item we observed for legitimisations of transitional justice (4.50), justification of former regimes' representatives in democratic public life (4.20), and explanations of symbolic roles of the democratisation (4.20). Less than four links per one field we identified for social costs of transformations (3.75), adaptation of new standards (3.60), new role in international politics (3.00), and legitimisation of the dominant position of new elites $(2.63)^{3}$.

Moreover, the Model presents spheres that have the strongest negative impact on the general intensity of transitional remembrance story-telling - the highest average per one field we observed for new state's identity in international relations (1.75, what is more than a half of all observed correlations for this area), position of new elites (0.83), new standards (0.80), social costs $(0.75)$, transitional justice (0.50), national unity $(0.25)$, presence of former elites $(0.20)$, and symbolic roles of the change (0.20). Therefore, the use of remembrance narratives to legitimise state's new international position was involved in seven of twelve negative correlations: three times with new elites, twice with transitional justice

\footnotetext{
${ }^{2}$ For explanation of the coded names, see the annex.

${ }^{3}$ Correlations between categories were counted once, while correlations within categories were counted as two-sided.
} 
and once with social costs and new standards. Other negative correlations linked new elites with symbolic explanation of the democratisation and adaptation of new standards, former elites with social costs, as well as new standards with social costs and with national unity. These observations show us an additional context of the dynamic of politicised remembrance during democratisations.

\section{DRAFT CONCLUSIONS}

In this research report we have presented the most significant results of our investigations on relations within the structure of transitional remembrance policy. The application of qualitative-to-quantitative narrative analysis enabled us to investigate links between individual objectives and aims of this policy in a context of governmental involvement in identity politics during democratisation. As a result, we present theoretical models that develop current state-of-arts in studies on political transformations and that may deliver valuable perspective for the theory of democratisation.

Our comparative study has delivered evidence to support a hypothesis that the intensity of use of remembrance narratives to explain symbolic roles of the change and justify social and economic costs of transformations has the strongest impact on the general intensity of remembrance story-telling during transition. It means that governments which try to present the national history as an argument for understanding the process in a wider, trans - and intergenerational context and which use it to explain long-lasting causes of social stratification and economic inequalities are more probable to be characterised by a higher interest in historical argumentation in general. However, as we noticed limitations of this discovery, we used our findings to construct a developed research tool - based on eight most relevant fields of impact - that can be used to predict the intensity of transitional remembrance story-telling (Marszałek-Kawa et al., 2016b, p. 102-108). 
ANNEX ONE

The Intensity of Use and the Strength of Correlations for Transitional Remembrance Policy's Areas and Field of Impact

\begin{tabular}{|c|c|c|c|c|}
\hline $\begin{array}{l}\text { Research } \\
\text { category }\end{array}$ & Code & Field of impact & Intensity & Correlation \\
\hline \multirow{7}{*}{$\begin{array}{l}\text { Legitimization } \\
\text { of new elites }\end{array}$} & $1-1$ & The past as a legitimization & 3,67 & 0.37 \\
\hline & $1-2$ & Use of the idea of state's continuity & 3,17 & 0.12 \\
\hline & $1-3$ & Use of national symbols and heroes & 3,00 & 0.44 \\
\hline & $1-4$ & New landscape of memory & 2,67 & -0.36 \\
\hline & $1-5$ & Counteracting internal conflicts & 2,17 & 0.46 \\
\hline & $1-6$ & Remembrance as a source of reconciliation & 1,67 & 0.27 \\
\hline & \multicolumn{2}{|r|}{ average: } & 2,72 & 0.31 \\
\hline \multirow{6}{*}{$\begin{array}{l}\text { Presence of the } \\
\text { former elite }\end{array}$} & $2-1$ & Counteracting internal conflicts & 3,67 & 0.39 \\
\hline & $2-2$ & As a legitimization of democracy & 3,00 & 0.43 \\
\hline & $2-3$ & As a definition of pluralism & 2,00 & 0.27 \\
\hline & $2-4$ & Building new political community & 2,83 & 0.30 \\
\hline & $2-5$ & Division between the past and the present & 1,50 & -0.66 \\
\hline & \multicolumn{2}{|r|}{ average: } & 2,60 & 0.46 \\
\hline \multirow{5}{*}{$\begin{array}{l}\text { Transitional } \\
\text { justice }\end{array}$} & $3-1$ & As a legitimization of the rule of law & 2,17 & 0.67 \\
\hline & $3-2$ & As a punishment for human rights violators & 1,50 & 0.81 \\
\hline & $3-3$ & As a source of forgiveness & 2,00 & 0.56 \\
\hline & $3-4$ & Limited scope of the transitional justice & 3,00 & 0.51 \\
\hline & \multicolumn{2}{|r|}{ average: } & 2,17 & 0.71 \\
\hline \multirow{5}{*}{$\begin{array}{l}\text { Social costs of } \\
\text { transformations }\end{array}$} & $4-1$ & The necessity of social costs of change & 2,33 & 0.09 \\
\hline & $4-2$ & New economic attitudes and behaviors & 1,17 & 0.72 \\
\hline & $4-3$ & The past as a source of stratifications & 1,50 & 0.56 \\
\hline & $4-4$ & The legitimization of the capitalism & 2,33 & 0.02 \\
\hline & \multicolumn{2}{|r|}{ average: } & 1,83 & 0.91 \\
\hline \multirow{6}{*}{$\begin{array}{l}\text { Adaptation of } \\
\text { new } \\
\text { social \& politi- } \\
\text { cal standards }\end{array}$} & $5-1$ & The historical necessity of changes & 2,83 & 0.24 \\
\hline & $5-2$ & The role of the intergenerational agreement & 2,33 & 0.23 \\
\hline & $5-3$ & National heroes as role-models & 2,67 & 0.57 \\
\hline & $5-4$ & $\begin{array}{l}\text { Balance between the tradition and the } \\
\text { modernization }\end{array}$ & 2,83 & 0.00 \\
\hline & $5-5$ & The past and a new definition of patriotism & 3,00 & 0.67 \\
\hline & & average: & 2,73 & 0.67 \\
\hline
\end{tabular}




\begin{tabular}{|c|c|c|c|c|}
\hline $\begin{array}{l}\text { Research } \\
\text { category }\end{array}$ & Code & Field of impact & Intensity & Correlation \\
\hline \multirow{6}{*}{$\begin{array}{l}\text { Symbolic } \\
\text { roles of the } \\
\text { democratization }\end{array}$} & $6-1$ & The intergenerational character of changes & 3,67 & 0.42 \\
\hline & $6-2$ & Democratization as a tribute for victims & 2,67 & 0.64 \\
\hline & $6-3$ & The pro-democratic selection of narratives & 3,00 & 0.84 \\
\hline & $6-4$ & National heroes as examples of behaviors & 3,50 & 0.75 \\
\hline & $6-5$ & New organization of time & 2,50 & 0.59 \\
\hline & \multicolumn{2}{|r|}{ average: } & 3,07 & 0.96 \\
\hline \multirow{5}{*}{$\begin{array}{l}\text { Historical need } \\
\text { for } \\
\text { the national } \\
\text { unity }\end{array}$} & $7-1$ & $\begin{array}{l}\text { The past as a legitimization of the national } \\
\text { unity }\end{array}$ & 3,50 & 0.63 \\
\hline & $7-2$ & Reasons for reconciliation and forgiveness & 2,83 & 0.25 \\
\hline & $7-3$ & Diversity of the landscape of memory & 2,33 & 0.07 \\
\hline & $7-4$ & Reconstruction of national heroes' pantheon & 2,17 & 0.46 \\
\hline & \multicolumn{2}{|r|}{ average: } & 2,71 & 0.56 \\
\hline \multirow{5}{*}{$\begin{array}{l}\text { New state's } \\
\text { identity } \\
\text { in international } \\
\text { relations }\end{array}$} & $8-1$ & Reasons for membership in IGOs & 2,83 & 0.19 \\
\hline & $8-2$ & $\begin{array}{l}\text { New identity as a fulfillment of } \\
\text { transformations }\end{array}$ & 3,17 & -0.24 \\
\hline & $8-3$ & (Re-)Gaining an appropriate position in IR & 3,83 & -0.18 \\
\hline & $8-4$ & Adaptation of new standards & 2,17 & 0.11 \\
\hline & \multicolumn{2}{|r|}{ average: } & 3,00 & -0.04 \\
\hline \multicolumn{3}{|l|}{ general average: } & 2,63 & - \\
\hline
\end{tabular}

Degrees of the use of remembrance narratives: 1 - very low, 2 - low, 3 - moderate, 4 - high, 5 - very high.

Calculations by Patryk Wawrzyński.

\section{REFERENCES:}

Blind, P.K. (2013). Policy-Driven Democratization. Geometrical Perspectives on Transparency, Accountability, and Corruption. New York: Palgrave Macmillan.

Bogaards, M. (2016). Microscope or Telescope? The Study of Democratisation Across World Regions. Political Studies Review. DOI: 10.1177/1478929916645360.

Capoccia, G., \& Ziblatt, D. (2010). The Historical Turn in Democratization Studies: A New Research Agenda for Europe and Beyond. Comparative Political Studies, 43 (8-9), 931-968.

Geddes, B. (1999). What Do We Know About Democratization After Twenty Years? Annual Review of Political Science, 2, 115-144. DOI: 10.1146/annurev.polisci.2.1.115. Geddes, B. (2009). What Causes Democratization? In: C. Boix \& S.C. Stokes (eds.), The Oxford Handbook of Comparative Politics (p. 317-339). Oxford: Oxford University Press. 
Godlewski, T. (2014). The Rulers and the Ruled - Civic Competence in Politics as a Criterion of Democracy. Polish Political Science Yearbook, 43, 363-376.

Kadivar, M.A., \& Caren, N. (2016). Disruptive Democratization: Contentious Events and Liberalizing Outcomes Globally, 1990-2004. Social Forces, 94 (3), 975-996.

Kącka, K. (2015). Polityka historyczna: kreatorzy, narzędzia, mechanizmy działania - przykład Polski. In: K. Kącka, J. Piechowiak-Lamparska, \& A. Ratke-Majewska (eds.), Narracje pamięci: między polityka a historia (p. 59-80). Toruń: Wydawnictwo Naukowe UMK.

Khalili, L. (2007). Heroes and Martyrs of Palestine. The Politics of National Commemoration. Oxford-New York: Oxford University Press.

Marszałek-Kawa, J., Piechowiak-Lamparska, J., Ratke-Majewska, A., \& Wawrzyński, P. (2016a). Polityka pamięci i kształtowanie tożsamości politycznej w czasie tranzycji poautorytarnej. Tom 1: Studia przypadku. Warszawa: Difin.

Marszałek-Kawa, J., Ratke-Majewska, A., \& Wawrzyński, P. (2016b). Polityka pamięci $i$ kształtowanie tożsamości politycznej $w$ czasie tranzycji poautorytarnej. Tom 2: Analiza porównawcza. Warszawa: Difin.

Marszałek-Kawa, J., \& Wawrzyński, P. (2016). Remembrance Narratives and Political Transitions: a Comparative Study. Polish Political Science Yearbook, 45, 11-21.

Papaioannou, E., \& Siourounis, G. (2008). Democratisation and Growth. The Economic Journal, 118 (532), 1520-1551.

Wawrzyński, P. (2015). Emocje i zaangażowanie a skuteczność narracji polityki historycznej. Wyniki badań eksperymentalnych. Pamięć i Sprawiedliwość, 14 (26), 159-182.

Wawrzyński, P., Muszyński, M.A., Czarnek, G., \& Schattkowsky, R. (2015). Individual Differences and Attitudes Towards the Government's Remembrance Policy. Polish Political Science Yearbook, 44, 125-139.

Westen, D. (2008). The Political Brain. The role of emotion in deciding the fate of the Nation. New York: Public Affairs. 